\title{
Species-specific abundance of bivalve larvae in relation to biological and physical conditions in a Cape Cod estuary
}

\author{
Christine M. Thompson ${ }^{1,3, *}$, Richard H. York ${ }^{2}$, Scott M. Gallager ${ }^{1}$ \\ ${ }^{1}$ Biology Department, Woods Hole Oceanographic Institution, Woods Hole, Massachusetts 02543, USA \\ ${ }^{2}$ Shellfish Constable, Town of Mashpee, Mashpee, Massachusetts 02649, USA \\ ${ }^{3}$ Present address: University of Maryland Center for Environmental Science, Horn Point Laboratory, Cambridge, \\ Maryland 21613, USA
}

\begin{abstract}
Physical and biological conditions impact recruitment and adult population structure of marine invertebrates by affecting early life-history processes from spawning to post-settlement. We investigated how temperature, salinity, and phytoplankton influenced larval abundance and larval size structure for 3 species of bivalves over 2 non-consecutive years in Waquoit Bay, Massachusetts, USA. Abundance and size of Mercenaria mercenaria (quahog), Anomia simplex (jingle clam), and Geukensia demissa (ribbed mussel) larvae were compared between locations in the bay and with environmental conditions. Shell birefringence patterns using polarized light microscopy were used to distinguish species. Larval abundances for all 3 species were higher in 2009 than in 2007 and were positively correlated with temperature in both years. Differences in larval abundance and size structure between bay sites were attributed to salinity tolerances and potential source locations. Higher survival in 2009 than in 2007, as determined by number of pediveligers, was likely due to higher temperatures and greater food availability during the peak abundance months of July and August in 2009. Yearly differences in larval growth and survival can have a large impact on recruitment. Knowing the optimal periods and locations for larval abundance and survival can be useful for isolating species-specific patterns in larval dispersal and to aid resource managers in enhancing or restoring depleted populations.
\end{abstract}

KEY WORDS: Bivalves · Larval supply $\cdot$ Transport $\cdot$ Spawning $\cdot$ Estuaries $\cdot$ Shellfish $\cdot$ Time series

\section{INTRODUCTION}

The dispersal and supply of planktonic invertebrate larvae has important consequences for benthic adult population structure (Roughgarden et al. 1988). The strength of larval flux to a given habitat or area can vary from year to year because of environmental conditions (Thorson 1950, Shirley \& Shirley 1989, Gaines \& Bertness 1992). Larval supply can be influenced by many factors, including the timing of larval release or spawning, local hydrographic effects, larval behavior, and quality of larvae (Scheltema 1986,
Todd 1998). Mean densities of bivalve larvae can vary greatly been consecutive years (Carriker 1961, Fegley 2001). Particularly for areas where commercial adult populations are managed, larval supply can be a link in the relationship between reproductive output and population growth (Botsford et al. 1998).

Understanding bivalve larval supply is essential to understanding the relationship between larval abundance and the population structure at later stages (Pineda et al. 2007, Cowen \& Sponaugle 2009). Many bivalve species are harvested commercially, and nat- 
ural population stocks are typically managed by studying adult survivorship and fecundity without accounting for the larval period (Orensanz et al. 1991). When measurements of adult reproductive effort do not support their subsequent recruitment, it could be due to larval success which is rarely measured. It is difficult to study pelagic larvae because of their microscopic size, short larval period compared to the adult lifespan, high mortality, and ability to disperse long distances (Levin 2006). A need for more in-depth studies of bivalve larvae has been expressed for years (Carriker 1988, Mann 1988), but progress has lagged behind that of other invertebrate larvae because of a lack of usable techniques to identify bivalve larvae at the species level (Garland \& Zimmer 2002).

Many of the biological and physical controls on bivalve larval abundance are subject to seasonal and annual variation that can affect yearly recruitment dynamics (Botsford et al. 1994). Wind speed and direction can affect estuarine retention time (Geyer 1997), leading to fluctuations in larval import and export from an estuary (Boicourt 1988, Gaines \& Bertness 1992, Belgrano et al. 1995). Adult spawning can be affected by water temperature and adult fecundity (Keck et al. 1975, Kassner \& Malouf 1982), which can affect larval survival, growth, and recruitment (Loosanoff et al. 1951, Davis \& Calabrese 1964, Brousseau 1977, Gallager et al. 1986, Pechenik et al. 1990, Dekshenieks et al. 1993). Areas of low salinity can be intolerable to certain species of bivalves (Loosanoff \& Davis 1963). Furthermore, environmental factors such as food availability and water temperature will affect the length of the larval period in the plankton (Bayne 1965, Hodgson \& Bourne 1988), which can affect survival and dispersal distance (Loosanoff et al. 1951, Jorgensen 1981, Raby et al. 1994, Wilson \& Meekan 2001). Timing of phytoplankton blooms has been shown to affect timing of larval abundance in barnacles, mussels and urchins (Starr et al. 1991), fish larvae (Townsend \& Cammen 1988), and crab larvae (Shirley \& Shirley 1989), but under estuarine conditions typical bloom patterns do not always occur (Litaker et al. 1987, Tomasky-Holmes 2008). These factors can vary spatially, with certain areas being more favorable for survival or retention than others. Although it is challenging to isolate the effects of one particular environmental variable on larval abundance and survival in the field, by concentrating on a few environmental variables over a long time series we may be able to discern which factors have a greater effect on larval abundance on a seasonal and bay-wide scale.
A majority of studies on larval bivalve growth and feeding have been performed in laboratories (e.g. Loosanoff \& Davis 1963), demonstrating growth and survival responses to temperature, salinity, and food availability (Loosanoff et al. 1951, Davis \& Calabrese 1964, Bayne 1965, Gallager et al. 1986, Dekshenieks et al. 1993). Effects of these factors on larval growth rates in the field are not well documented due to challenges with larval sampling, as well as confounding factors such as advection and mortality due to predation. A few studies have attempted to follow growth and survival of larval cohorts from estimates of their size-frequency distributions (Jorgensen 1981, Chicharo \& Chicharo 2001, Rigal et al. 2010), but this is most applicable for closed systems with high retention.

The purpose of our study was to investigate the biological and physical factors affecting larval abundance and survival of 3 bivalve species in 2007 and 2009 in Waquoit Bay, an embayment on Cape Cod, Massachusetts. Mercenaria mercenaria (quahog) is a commercially important shellfish resource for the bay and is found in open waters with sandy bottoms. Guekensia demissa (ribbed mussel) grows along the banks in marsh channels and plays an ecologically important role by filtering particles and removing nitrogen (Jordan \& Valiela 1982) and by stabilizing shorelines and fertilizing marsh plants (Bertness 1984). Anomia simplex is a widespread fouling organism around Cape Cod, often found attached to rocks and shells (Eckman 1987). We compared time series of abundance and size of these 3 species of bivalve larvae from 4 sites in Waquoit Bay from May through mid-October (when water temperatures exceeded $15^{\circ} \mathrm{C}$ ) and applied a state-of-the-art image-analysis method using shell birefringence patterns to distinguish larval species (Tiwari \& Gallager 2003a,b, Thompson et al. 2012). Environmental conditions prevailing during 2 non-consecutive years of data collection allowed us to compare a warm, dry year (2007) to an initially cooler, wet year (2009). We hypothesized that better food quality in 2009 would result in more growth and show better survival of larvae. We used abundance of pediveliger larvae as a proxy for larval survival to competency as we were unable to estimate growth rates. We addressed the following questions: (1) Does larval abundance and survival differ spatially and temporally? and (2) How do environmental variables at each site and between years influence larval supply? This study presents a novel effort to address species-specific questions in bivalve larval supply in Waquoit Bay and relate them to population dynamics and management. 


\section{MATERIALS AND METHODS}

\section{Study site and sampling locations}

Waquoit Bay is a $16 \mathrm{~km}^{2}$ estuary on the south shore of Cape Cod, Massachusetts, USA. The average depth in the bay is $2.5 \mathrm{~m}$, with an average tidal range of about $0.5 \mathrm{~m}$ (Howes et al. 2004). Waquoit Bay exchanges water with outer Nantucket Sound through 2 inlets with a residence time of 2 to $3 \mathrm{~d}$ and is subject to occasional enhancement or reduction of exchange via wind forcing (Geyer 1997). The main freshwater input to Waquoit Bay is through groundwater, but several sub-embayments exchange water with the main bay and vary with freshwater and nutrient inputs (Howes et al. 2004). Residence times in the sub-embayments are longer than in the main bay on the order of several days to weeks (Howes et al. 2004, Tomasky-Holmes 2008). We sampled at 4 sites representing different areas of the bay (Fig. 1). The Menauhant site $(\mathrm{MN})$ is the western inlet to the bay, Little River (LR) is a well-mixed sub-embayment on the eastern side, Waquoit Bay-Metoxit Point site (WB) is located in the middle of the bay proper, and the Childs River site (CR) is a sub-embayment upstream of the western inlet and has the lowest salinities and high nitrogen concentrations. In 2007 weekly samples were taken from 23 May to 26 October, and in 2009 samples were taken weekly from 7 May to 14 October. These periods correspond to temperatures exceeding $15^{\circ} \mathrm{C}$, which cause spawning of most local bivalves.

\section{Larval sampling procedure}

On each sampling date, all 4 sites were sampled within 3 to $5 \mathrm{~h}$. The Waquoit Bay-Metoxit Point (from hereon Waquoit Bay) samples were taken from a boat both years. At each other site, samples in 2007 were taken from a boat and the samples in 2009 were taken from the same dock the boat samples were taken from to save time. A bilge pump (West Marine BilgePro 2200) attached to a hose and powered either from the boat console or a portable $12 \mathrm{~V}$ battery was used to collect samples at a flow rate of 18 to $24 \mathrm{l}$ $\mathrm{min}^{-1}$. Samples were taken by slowly moving the pump through the surface to $20 \mathrm{~cm}$ above the bottom in order to get a depth-integrated sample of 100 to $200 \mathrm{l}$. Water was filtered through a $53 \mu \mathrm{m}$ nylon mesh PVC screen with a pre-screen of $333 \mu \mathrm{m}$ mesh which was discarded. The pre-screen may have removed some large pediveliger larvae, but none were found

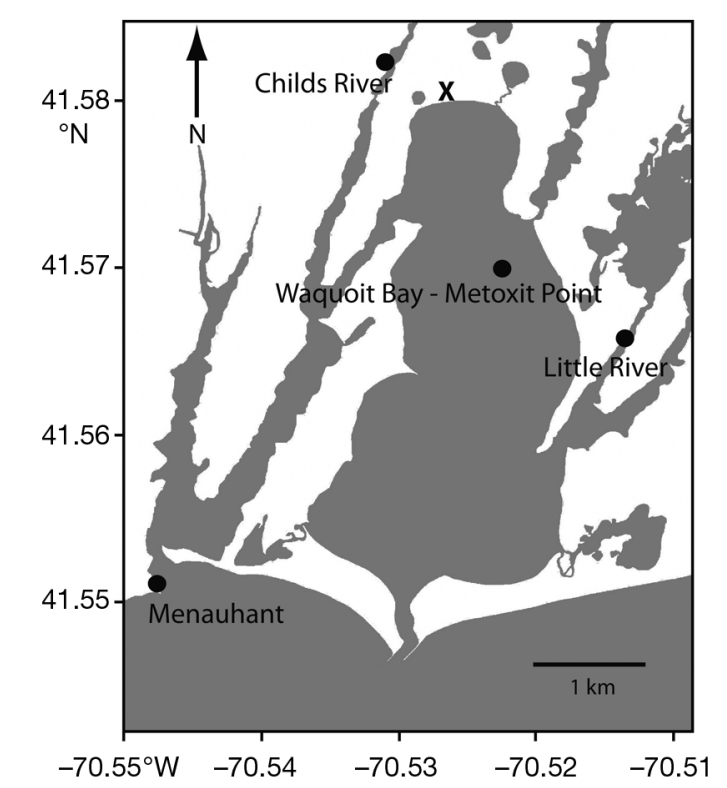

Fig. 1. Map of Waquoit Bay showing the 4 larval sampling sites (black dots). The ' $\mathrm{X}$ ' marks the location of the Waquoit Bay National Estuarine Research Reserve and weather station where wind data was collected

in select $333 \mu \mathrm{m}$ fractions that were collected. All filtered samples from the $53 \mu \mathrm{m}$ fraction were immediately preserved in $4 \%$ buffered formalin.

\section{Sample processing and larval identification}

Plankton samples were first counted in full or by volumetric sub-sampling for denser samples (to ensure at least 300 individuals were counted per sample) under a dissection microscope. Volumes were standardized to $1 \mathrm{~m}^{3}$. One-hundred larvae were then subsampled from the total sample (or the total sample was used if it contained $<100$ individuals) and individually imaged using a Zeiss IM35 microscope fitted with a Moticam 1000 digital camera, polarization filter, and full wave compensation plate. Motic Images Plus (Version 2.0; Motic China Group) was used to capture each polarized image.

Several criteria for identification were used to ensure accuracy. Field identification guides of Chanley \& Andrews (1971) and Loosanoff et al. (1966) were used for morphology and size criteria. A polarized image library of confirmed hatchery reared and molecularly identified field-collected larvae was used to confirm birefringence patterns for each species. These patterns have been shown to be species specific and can aid in larval identification (Tiwari \& Gallager 2003a,b, Thompson et al. 2012). Based on 
these criteria, we visually sorted images into 14 species categories. Only the larval images that were identified as Anomia simplex, Geukensia demissa, or Mercenaria mercenaria, composing about one-third of the total images, were used in further analysis, as library images of these species were identified using PCR methods (Hare et al. 2000). These sorted larvae were used to test an automated image-analysis method. Accuracies from control tests using these criteria to visually sort 4 species of known larvae ranged from 85 to $100 \%$ and were not significant between size classes (Thompson et al. 2012); however, accuracies for both visual and automated methods are expected to decrease with increasing numbers of species categories. Agreements with manually classified larvae (present study) and computer-classified larvae using a 6 -species training set ranged from 72 to $82 \%$ for the 3 species studied here, which provides some estimate of the accuracies of the classifications in this study.

Measurements of each larval shell were made by masking each larval image from its background and cropping it to only the region of the larval shell. An edge-detection image analysis routine in MATLAB (Version R2009a; Mathworks) was used to obtain major and minor axes in pixels, which were converted to microns by calibration with a stage micrometer. To assess abundance of pediveliger larvae, we used larvae $>200 \mu \mathrm{m}$ as a cutoff for Mercenaria mercenaria and Geukensia demissa and >175 $\mu \mathrm{m}$ for Anomia simplex based on literature estimates (Chanley \& Andrews 1971).

\section{Phytoplankton counts}

Alongside each larval sample, $100 \mathrm{ml}$ of unfiltered water was sampled from the water column. Phytoplankton were identified and counted on a hemacytometer slide with a light microscope a few hours after collection. Cell sizes were measured with an optical micrometer. Subsamples of $10^{-3}$ to $10^{-1} \mathrm{ml}$ were counted depending on phytoplankton density. The larger volumes were examined by counting multiple chambers per sample.

\section{Environmental data}

Measurements of temperature, salinity, pressure (depth), chlorophyll a fluorescence, and other parameters were recorded in 15 min intervals from moored units (YSI 6600 sonde, YSI) at each sampling location
(Fig. 1). Three sites (MN, WB, and CR) were maintained by the Waquoit Bay National Estuarine Research Reserve's (WBNERR) seawater quality monitoring program (SWMP), and the Little River instrument was maintained by the Mashpee Shellfish Constable. Wind speed and direction were recorded from a weather station at the WBNERR facility on the north end of Waquoit Bay. Data from these instruments were averaged daily during the sampling period.

A handheld instrument (YSI 650 MDS, YSI) recorded instantaneous temperature, and salinity at the time and location of plankton collection. Measurements were taken at the surface, middle, and bottom of the water column. Values at these depths were averaged for each sample. If salinity and/or temperature differed by 1 unit or more between the surface and bottom, the water column was considered stratified.

\section{Time series analysis}

Autocorrelation analysis on time series of each species' concentration and mean size at each site was performed to determine the scale of independence for the samples and if there was periodicity. Series means were initially subtracted from each value to detrend the data prior to analysis. Only autocorrelations at lags of 1 to $2 \mathrm{wk}$ were considered meaningful based on the total length of the time series $(<20 \%$; Emery \& Thomson 1997). To determine if larval abundance and size structure were coherent between sites, cross-correlation analyses were performed between pairs of sites for species concentrations and mean sizes. Data were lagged in both directions by weekly time steps. In the few cases of missing data points due to a lost sample or instrument failure (no more than 2 per series), the missing data point was interpolated using a quadratic spline to ensure continuity of the time series for analysis. The time scale for independent samples for each time series was determined by the time point where the autocorrelation was no longer significantly different from zero (alpha $=0.05)$. Degrees of freedom were calculated by dividing the total length of the time series by the time scale for independent realizations. Although this is a less conservative approach than using decorrelation times (the time point when the autocorrelation function crosses the $x$-axis), we chose this method because the time series only had 24 points and most of the time series data were not autocorrelated. 
We explored possible associations between larval concentrations and physical measurements of temperature, salinity, and chl a using the autocorrelation and cross-correlation methods described in the previous section. For these cross-correlations, the log of larval concentration was used to normalize the variance of the larval time series with respect to the physical variables. Temperature and salinity values were recorded simultaneously with each larval sample, and chl a fluorescence from the continuous records was averaged for the tidal period when the sample was taken. We only regarded correlations with salinities at no time lags to be biologically relevant, as the salinity time series oscillates predominately at a tidal frequency, much shorter than our weekly sampling interval. All statistical tests were performed using MATLAB and SYSTAT (Version 12.0; SPSS) software.

\section{RESULTS}

\section{Environmental setting}

Records from water-quality monitoring instruments from the main bay site (WB) indicate that bay-water temperatures in spring and early summer in 2007 were warmer and had lower chl a concentrations than in 2009 (Fig. 2a,c). Initial spawning temperatures $>16^{\circ} \mathrm{C}$ occurred in May at all sites, ideal spawning temperatures $>20^{\circ} \mathrm{C}$ were reached by late May in 2007, but not until late June in 2009. Temperatures warmed earlier at the Little River site (Thompson 2011). During August, water temperatures and chl a concentrations were higher in 2009 than in 2007. Salinities were similar between the 2 yr. Salinity oscillated around 27 to $32 \mathrm{psu}$, with slightly fresher bay water in 2009 (Fig. 2b).

We grouped phytoplankton into flagellate and diatom categories to represent available food sources for larvae (Fig. 3). Flagellates included dinoflagellates and represent the background available food source for larvae in the bay, and diatoms found were in both pennate (such as Nitzschia sp.) and centric forms (Chaetocerous sp., Thalassiosira sp., Skeletonema sp.) and represent a more nutritious source when available. Food was extremely low in Little River, Menauhant, and the main bay (WB) (Fig. 3a,b,d) in May and June 2007. The higher chl a observed in 2009 was a result of diatom blooms starting in mid-June.

The typical southwest wind pattern prevalent for southern Cape Cod in summer was observed in both years (Fig. 4), with average onshore wind speeds around 0.5 to $1 \mathrm{~m} \mathrm{~s}^{-1}$. This would lead to increased freshwater buildup and stratification within the bay (Geyer 1997). In spring and fall of 2009 there were sporadic storm events changing wind speed and direction, leading to more mixing and flushing of bay water during these periods.

\section{Species-specific concentration and size distribution}

Concentrations of all 3 species were higher in 2009 than in 2007 (Figs. 5 to 7). For both years, peak abundance occurred in July and August. For Anomia simplex, larvae were present from late June through August in 2007 and from June through September 2009, with a few individuals into October in 2009 (Fig. 5). This species appeared to spawn weekly throughout its period of abundance, with large portions of smaller larvae and pediveligers appearing simultaneously. A. simplex was observed first in the inlet site (MN) in 2007, but in 2009 the inner bay
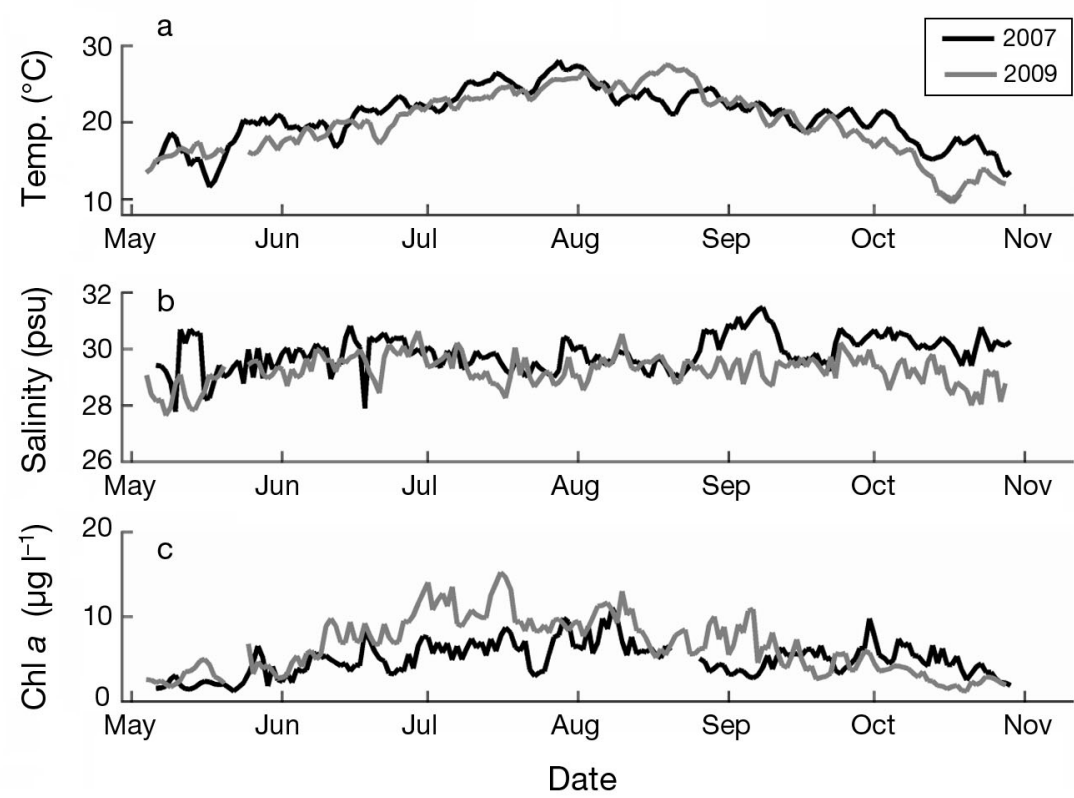

Fig. 2. Daily averaged (a) temperature, (b) salinity, and (c) chlorophyll a for Waquoit Bay-Metoxit Point. All recorded data were averaged daily from moored loggers for the sampling periods of May through October in 2007 and 2009 

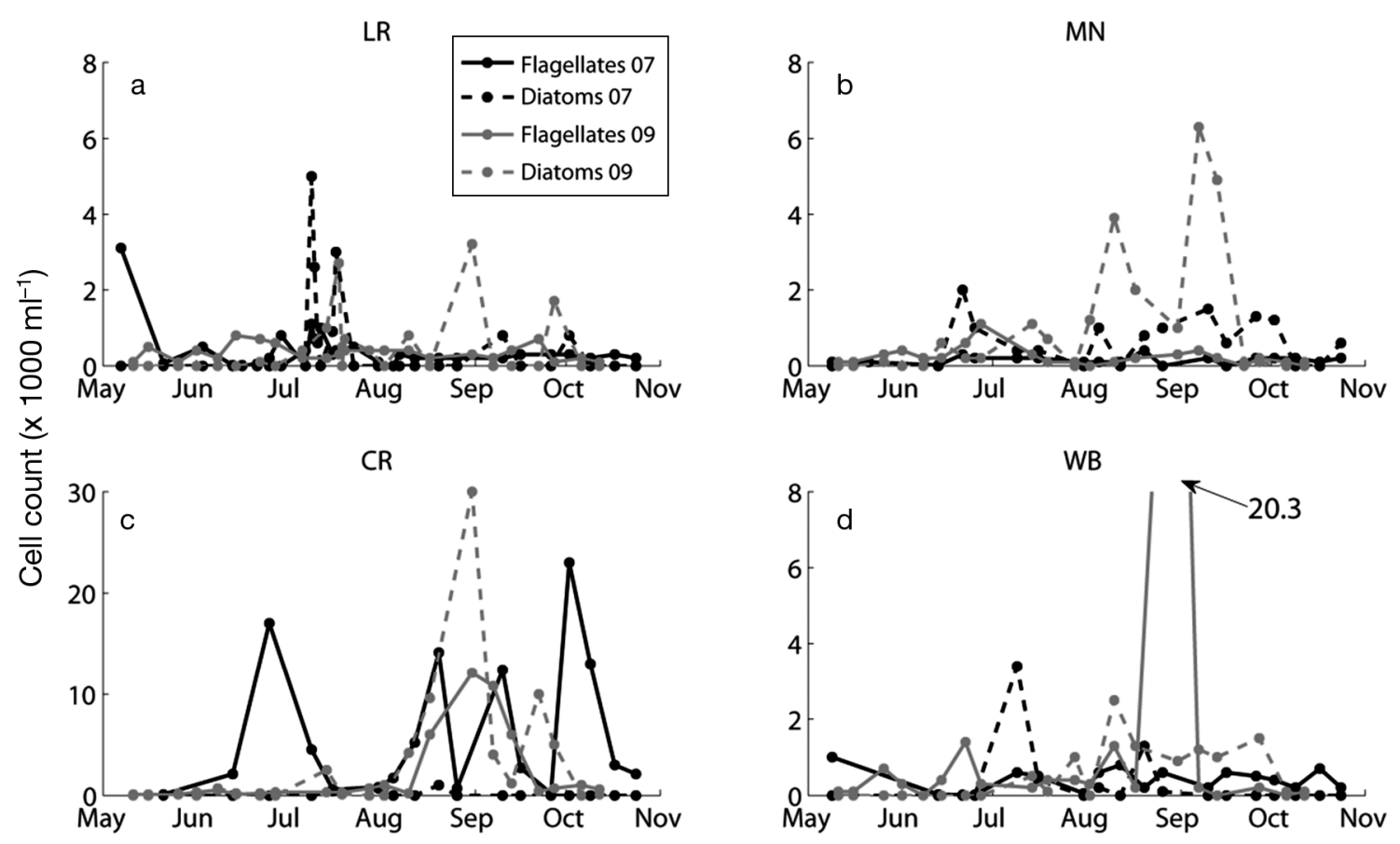

Fig. 3. Phytoplankton counts for all sites in 2007 (black) and 2009 (gray). Total counts of flagellates (solid lines) and diatoms (dashed lines) from water samples on each sampling date are plotted for each site. Flagellates included counts for flagellates and dinoflagellates, and diatoms consisted of centric (Chaetoceros sp., Skeletonema sp., Thalassiora sp.) and pennate (Nitzchia sp.) forms. Note the different axis scale for (c) and outlier value of 20.3 in (d). Site abbreviations - LR: Little River; CR: Childs River; MN: Menauhant; WB: Waquoit Bay-Metoxit Point

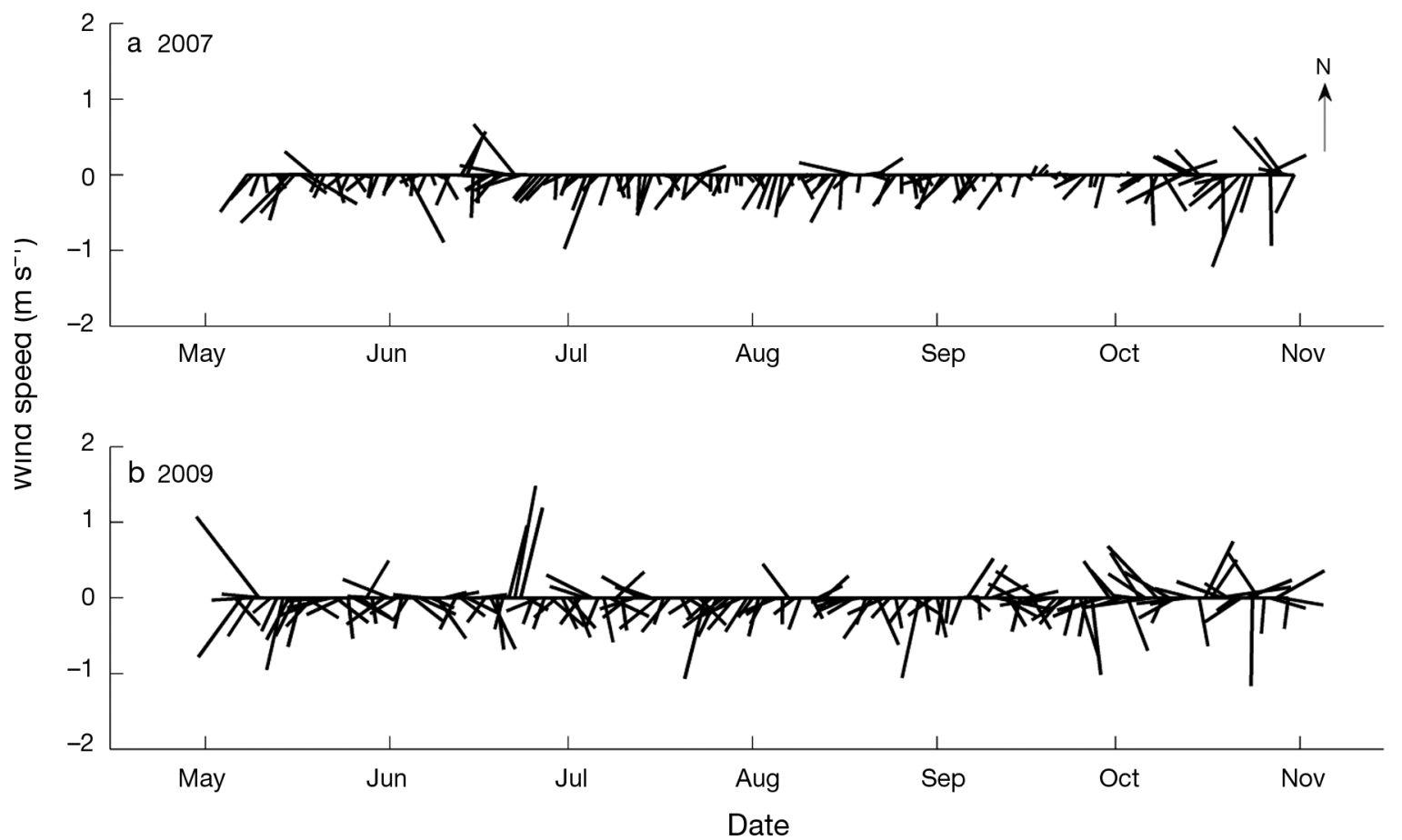

Fig. 4. Time series of wind vectors for Waquoit Bay-Metoxit Point in (a) 2007 and (b) 2009. Wind speed (m s${ }^{-1}$ ) and direction were averaged daily from May through October for both years. The weather station was located at the northern tip of the bay at the Waquoit Bay-Metoxit Point National Estuarine Research Reserve 

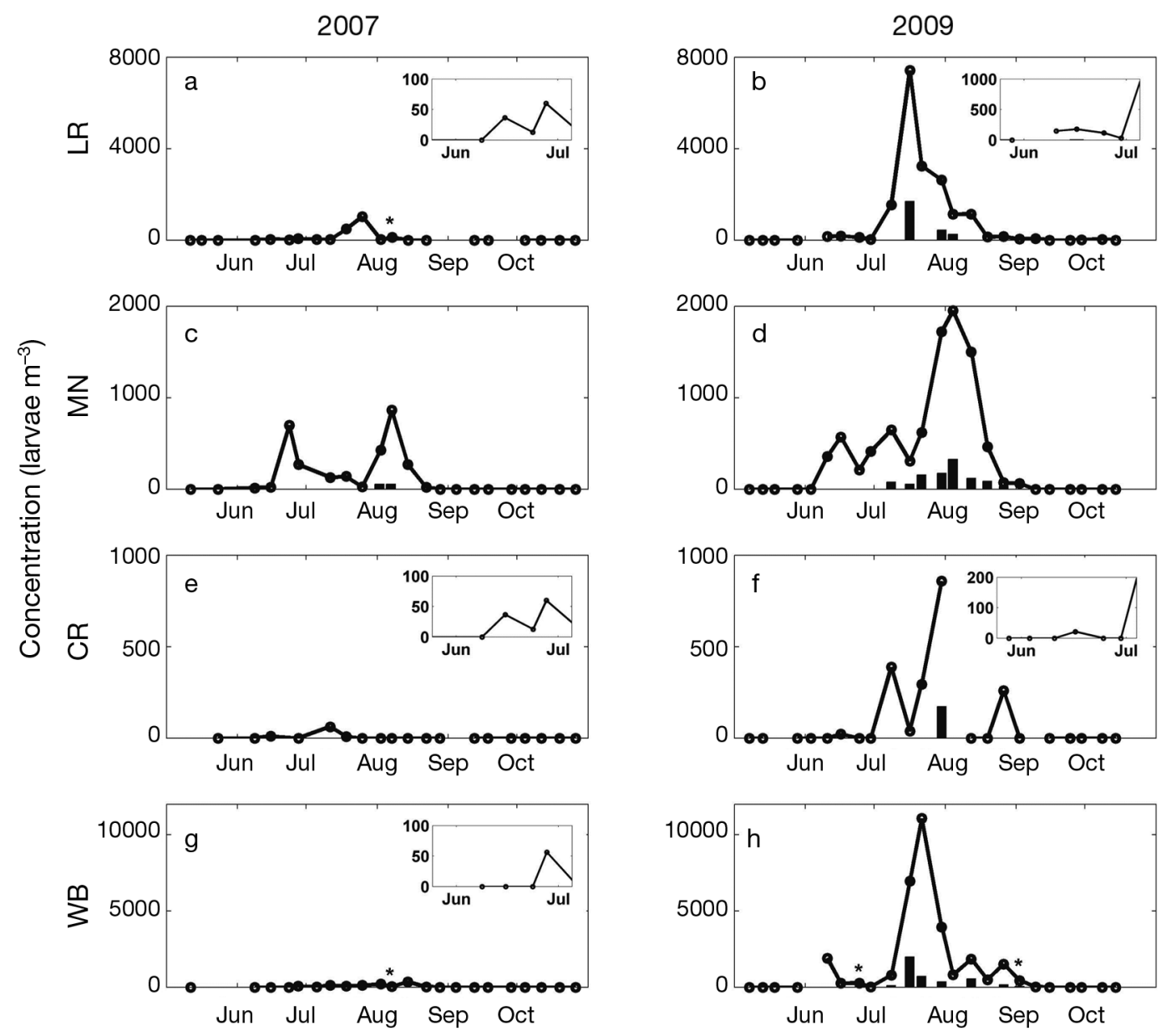

Fig. 5. Anomia simplex. Time series of A. simplex larvae at each sampling site in (a,c,e,g) 2007 and (b,d,f,h) 2009. Black lines show total concentration, and bars underneath represent concentration of pediveliger ( $>175 \mu \mathrm{m})$ larvae. Inserts show a zoomed-in area to depict trends if not visible on the full graph. Asterisks represent samples where pediveliger larvae were present but concentrations were too small to appear on the figure. Site abbreviations - LR: Little River; CR: Childs River; MN: Menauhant; WB: Waquoit Bay-Metoxit Point

sites, Waquoit Bay and Little River, had the highest early concentrations. Few A. simplex were observed at Childs River. Pediveliger larvae were present throughout July and August of 2009 for all sites except Childs River, indicating more survival. Pediveligers only appeared 1 to 2 times at any site in 2007.

Larvae of the ribbed mussel Geukensia demissa were mostly observed July through October both years, with some spawning in late June in 2007 (Fig. 6). Two distinct and equal spawning events were observed in 2007, while in 2009 there was a mass spawn in July and a smaller spawn afterwards (with the exception of Childs River which had 3 large peaks). Abundances were greatest at Little River and Childs River where marshes are prevalent. In 2009, G. demissa larvae were first observed from the
Menauhant inlet site, far from the upper marsh regions where adults are more abundant. Pediveligers were present in August in 2007 and July through September in 2009, but in lower abundance compared to the other species.

Mercenaria mercenaria larvae appeared the earliest (May to June) of all the species, suggesting a lower spawning temperature threshold (Fig. 7). Little River and Waquoit Bay had the highest concentrations of larvae in 2009, but in 2007 the highest concentrations were observed at the inlet and less from the bay sites. $M$. mercenaria concentrations had biweekly peaks in 2007 and 2009, with modes in July and August. Pediveliger larvae were prevalent in 2009 at all sites with the highest concentrations in August and lasting through October, but only occurred at Waquoit Bay in 2007. 

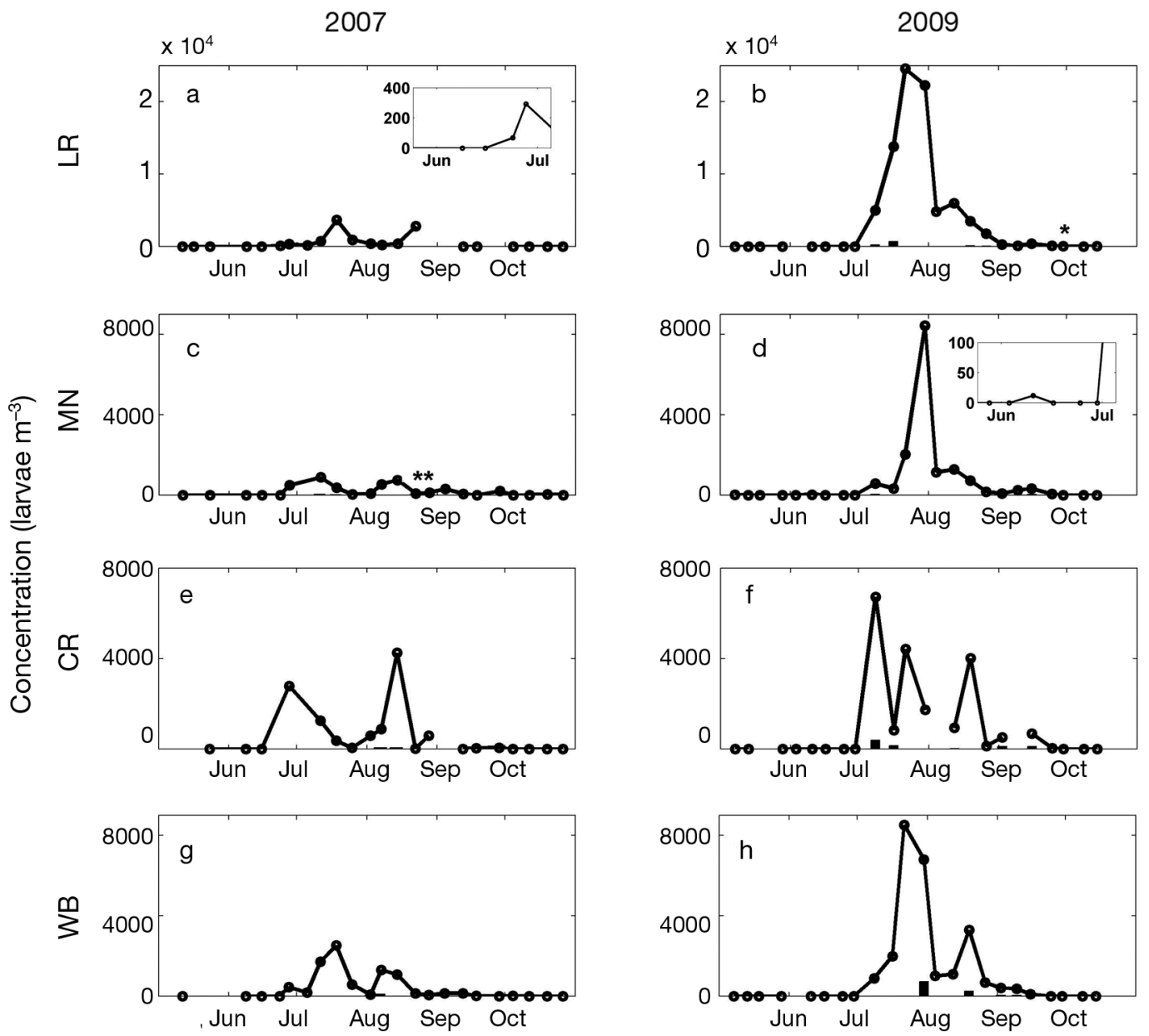

Fig. 6. Geukensia demissa. Time series of G. demissa larvae at each sampling site in (a,c,e,g) 2007 and (b,d,f,h) 2009. Black lines show total concentration, and bars underneath represent concentration of pediveliger ( $>200 \mu \mathrm{m})$ larvae. Inserts show a zoomed-in area to depict trends if not visible on the full graph. Asterisks represent samples where pediveliger larvae were present but concentrations were too small to appear on figure. Site abbreviations - LR: Little River; CR: Childs River; MN: Menauhant; WB: Waquoit Bay-Metoxit Point

\section{Spatial patterns in concentration and mean size}

Correlations were performed as a way to assess the consistency, or coherence, of larval abundance and size with space and time. There was no significant autocorrelation beyond a $1 \mathrm{wk}$ lag for either year for both the abundance and mean size time series for all species, with the exception of Geukensia demissa abundance at Childs River in 2009, which was correlated for $3 \mathrm{wk}$. We subtracted degrees of freedom by 2 or 3 for the autocorrelated time series in the crosscorrelations. Significant correlations between sites (no lags) are depicted in Fig. 8. All correlation coefficients and significant lag times are reported in Figs. S1 \& S2 in the supplement at www.int-res.com/ articles/suppl/m469p053.pdf.
Comparing locations, there were significant correlations in abundance between the sites on the eastern sides of the bay (LR and WB sites) and the western channels (MN and $\mathrm{CR}$ ), though these relationships were not consistent for all species or for both years. Anomia simplex was the least well-mixed species in the bay, showing consistent separation between sites. In 2007, A. simplex concentrations at both Menauhant and Waquoit Bay lagged behind Little River by 1 to 2 wk ( $r=0.73$ and 0.52 , respectively), and no sites were correlated with Childs River. Mean sizes were significantly correlated for the 3 lower sites (Fig. 8a), and also lagged 2 wk behind Little River $(r=0.73$ for $\mathrm{MN}$ and $\mathrm{r}=0.91$ for WB). In 2009, Little River and Waquoit Bay were significantly cross-correlated for A. simplex abundance 

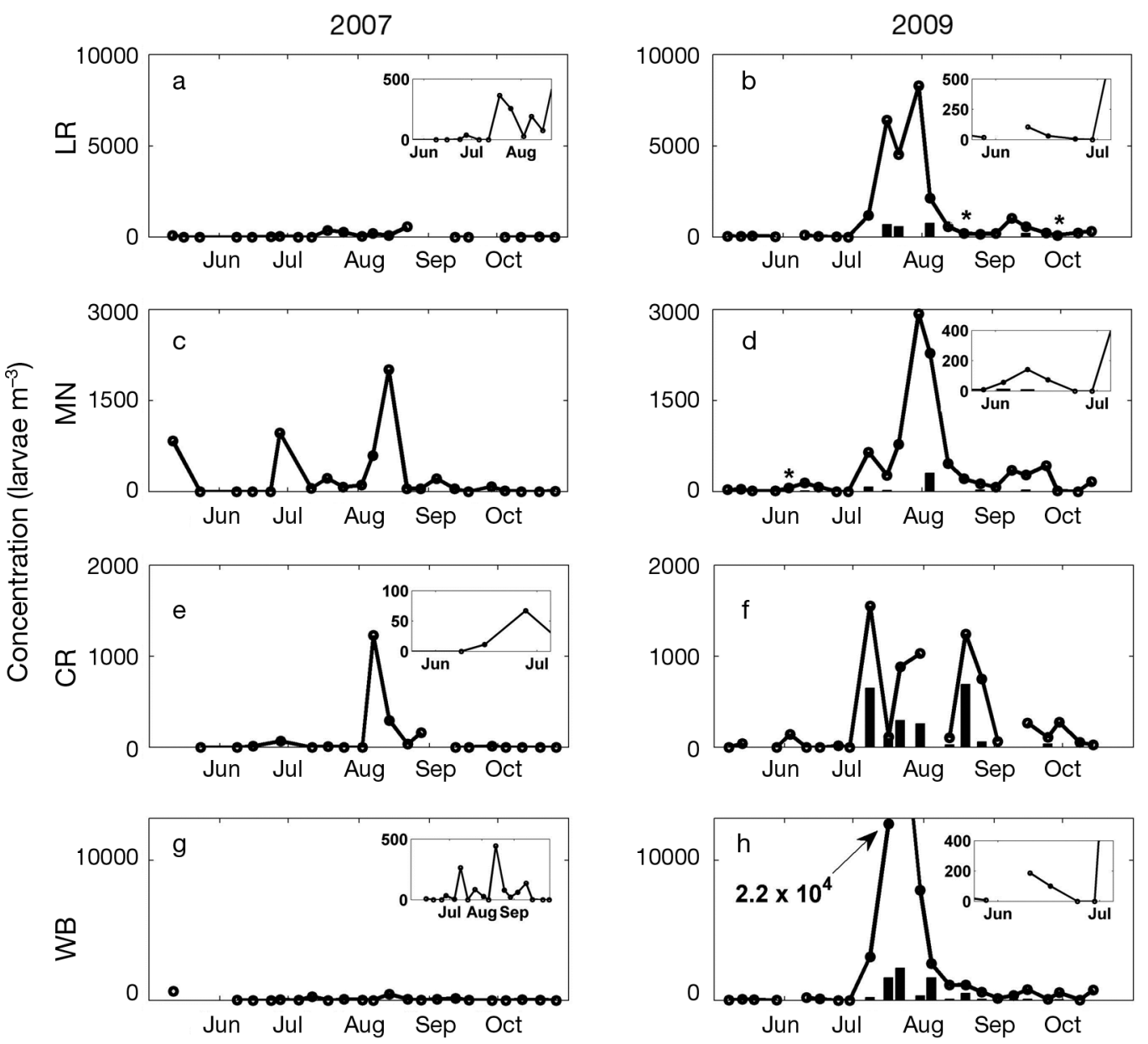

Fig. 7. Mercenaria mercenaria. Time series of M. mercenaria larvae at each sampling site in (a,c,e,g) 2007 and (b,d,f,h) 2009. Black lines show total concentration, and bars underneath represent concentration of pediveliger ( $>200 \mu \mathrm{m})$ larvae. Inserts show a zoomed-in area to depict trends if not visible on the full graph. Asterisks represent samples where pediveliger larvae were present but concentrations were too small to appear on figure. Site abbreviations — LR: Little River; CR: Childs River; MN: Menauhant; WB: Waquoit Bay-Metoxit Point

$(\mathrm{r}=0.79)$, as were Menauhant and Childs River $(\mathrm{r}=$ $0.66)$, and there was a $2 \mathrm{wk}$ lag in cross-correlations between the 2 sides of the bay (Fig. 8b).

Geukensia demissa was more well-mixed between sites in 2009, but in 2007 there was some spatial separation between east and west sites. G. demissa concentrations at Waquoit Bay were correlated with both Little River and Menauhant (Fig. 8c; $r=0.62$ and $r=$ 0.73, respectively), and Menauhant was correlated with Childs River $(r=0.76)$. Waquoit Bay and Little River concentrations had significant 1 wk lags behind Menauhant and Childs River (WB-MN r = 0.67, LR-MN $\mathrm{r}=0.71, \mathrm{LR}-\mathrm{CR} \mathrm{r}=0.51$ ). Only Menauhant and Childs River had correlations with sizes in $2007(\mathrm{r}=0.65)$, and all sites were lagged to Little River. In 2009, positive and significant correla- tions were observed between Little River, Waquoit Bay, and Menauhant (LR-WB r $=0.94$, LR-MN r = 0.75, MN-WB $\mathrm{r}=0.74$ ) and between Childs River and Waquoit Bay ( $r=0.58)$ in 2009 (Fig. 8d). All mean sizes were strongly correlated in 2009, indicating strong coherence in population structure throughout the bay (LR-MN r $=0.59$, LR-CR r $=0.66$, LR-WB r $=$ $0.66, \mathrm{MN}-\mathrm{CR} \mathrm{r}=0.71, \mathrm{MN}-\mathrm{WB} \mathrm{r}=0.80$ ).

Mercenaria mercenaria had little population coherence in 2007, but high coherence among the more downstream sites in 2009. In 2007, abundances at Menauhant and Waquoit Bay had a significant correlation ( $\mathrm{p}=0.69)$, and Little River abundances lagged behind all other sites by 1 to 2 wk (Fig. 8e). All sites lagged behind Childs River. In 2009, Little River abundances and sizes were significantly correlated 
2007

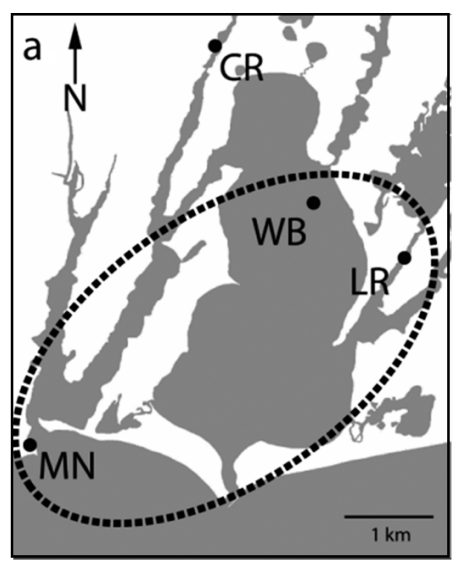

AS

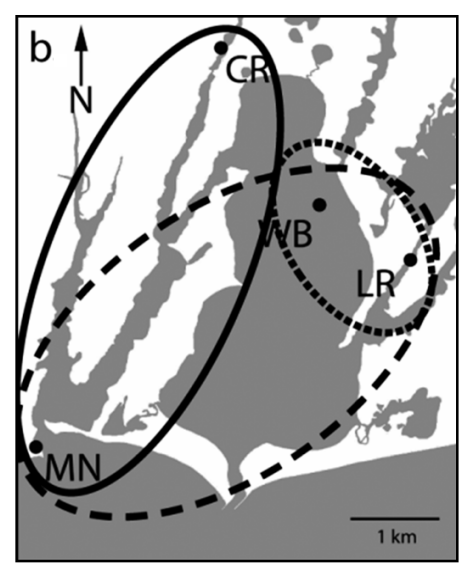

GD
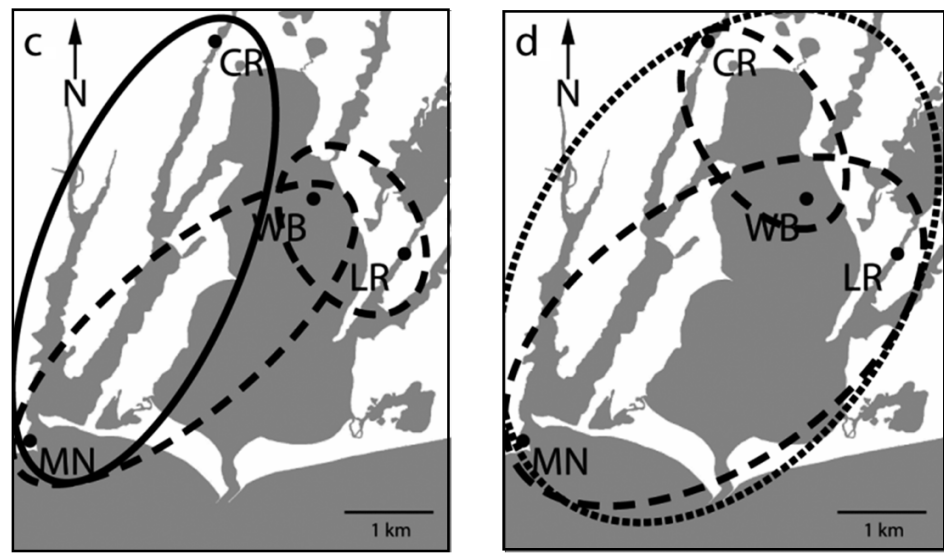

$\mathrm{MM}$
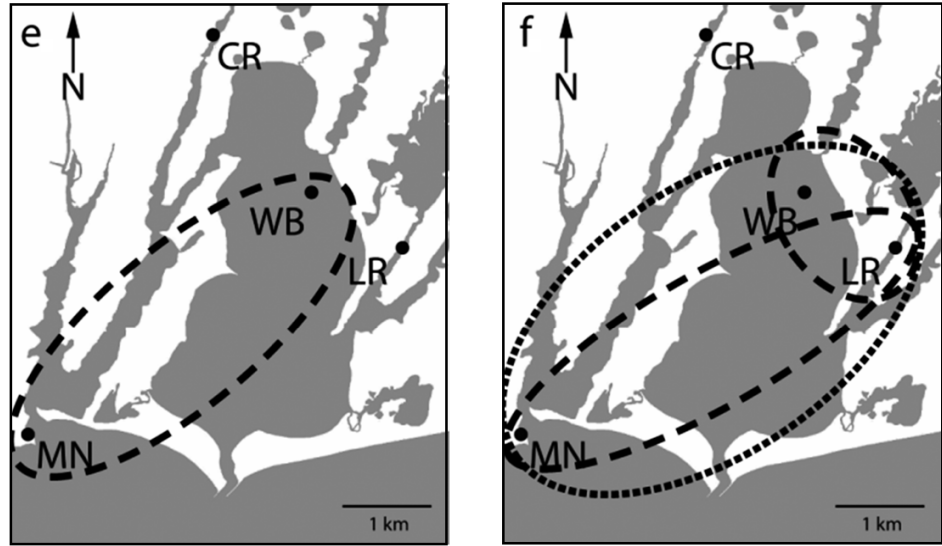

Fig. 8. Correlations between time series of concentrations and mean size of bivalve larvae. Ellipses represent positive and significant cross-correlations $(p>0.05)$ between sampling sites. Long dashed lines represent correlations between concentrations of larvae and short dashed lines represent correlations between mean size of larvae. Solid lines represent significant correlations for both concentration and mean size. Species abbreviations-AS: Anomia simplex; GD: Geukensia demissa; MM: Mercenaria mercenaria. Site abbreviations - LR: Little River; CR: Childs River; MN: Menauhant; WB: Waquoit Bay-Metoxit Point with the Menauhant and Waquoit Bay sites $(\mathrm{LR}-\mathrm{MN} \mathrm{r}=0.71 / 0.52, \mathrm{LR}-\mathrm{WB} \mathrm{r}=0.76 / 0.79)$, and Childs River lagged behind Little River by $1 \mathrm{wk}(\mathrm{r}=0.63)$. Similar to the other species, M. mercenaria time series at Childs River were not correlated with many other sites.

\section{Relationship to environmental factors}

Cross-correlations between environmental conditions and individual species suggested that temperature was most influential at predicting larval abundance for each species on a temporal scale, but salinity was more important on a spatial scale. We compared the abundance and distributions of each species in relation to average water column temperature and salinity by plotting larval concentration (on a log scale) as a function of both these variables (Fig. 9). Childs River was almost always stratified when samples were taken, while Menauhant and Wauquoit Bay were occasionally stratified.

Bivalve larvae were commonly found in samples taken during high temperature and salinity conditions. Temperature and salinity trends were similar for both years, though 2009 had a wider range of salinities, due to lower Childs River salinities (Fig. 9; squares). Little River (Fig. 9; circles) had the highest ranges of observed temperatures in 2007, and Little River and Menauhant (Fig. 9; triangles) had the highest ranges of temperatures in 2009. Results from both years showed that larval concentrations peak above $20^{\circ} \mathrm{C}$, indicating that these 3 species are warm-water spawners. Salinity ranges were broader for Geukensia demissa, with abundant samples through mid-salinity ranges, but Anomia simplex and Mercenaria mercenaria favored higher salinities (Fig. 9).

Temperature was the environmental variable that had the most significant correlations with time series of larval concentration (Fig. 10). Cross-correlations were significant between temperature and Anomia simplex and Geukensia demissa concentration in both years, with the exception of $A$. simplex at Childs River in 2007. In 2009, all species and sites were positively and significantly correlated with temperature, with the excep- 

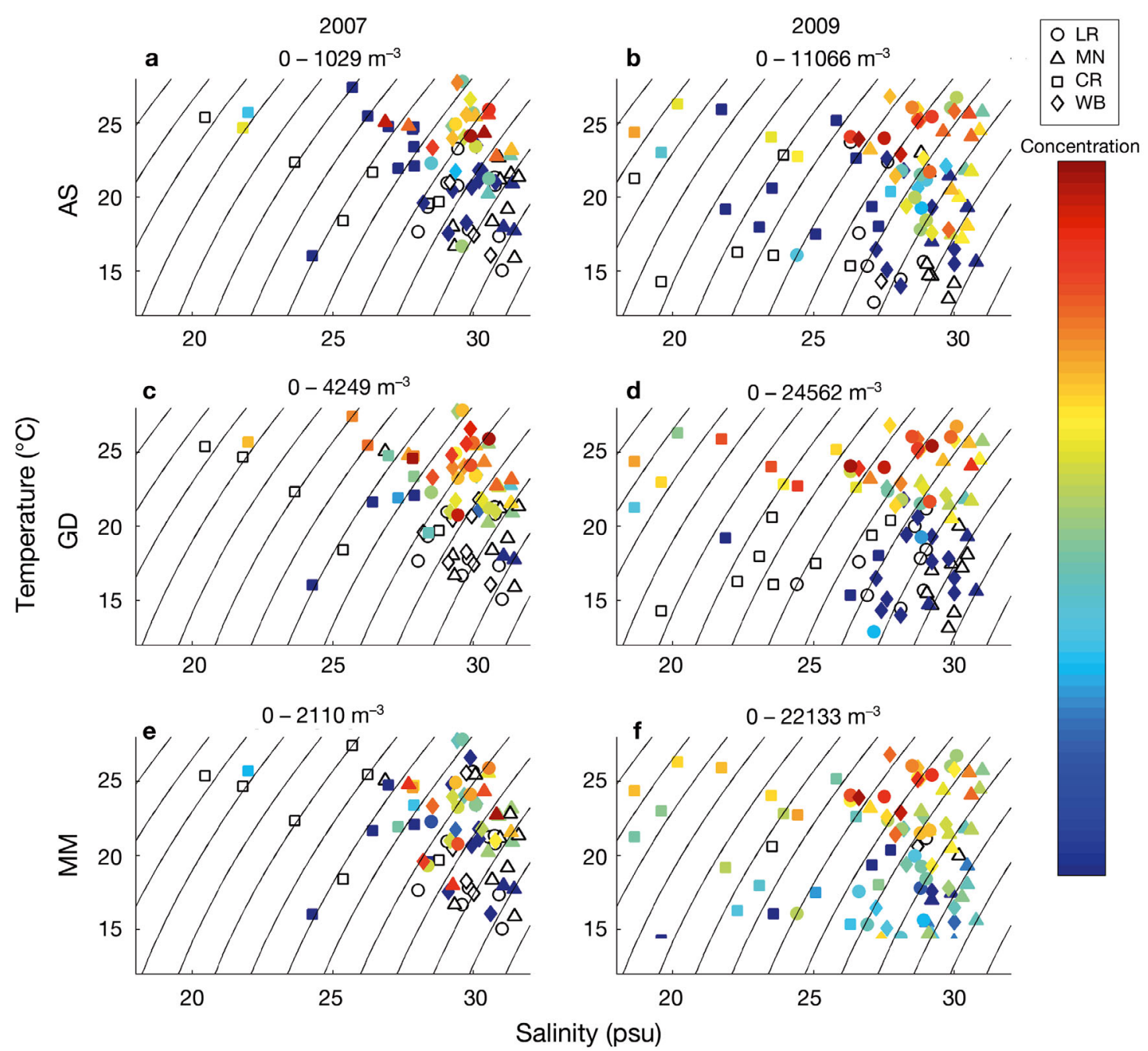

Fig. 9. Temperature-salinity-plankton plots of 3 species of bivalve larvae at all 4 sites in (a,c,e) 2007 and (b,d,f) 2009 . The location of each data point represents the temperature and salinity as recorded during each sample. The color of each point represents the concentration of each species as determined from the percentage observed in each subsample and total concentration. Numbers at the top of each figure are the range of concentrations for each species that corresponds to the color bar. Concentrations are on a log scale. Site symbols see key; unfilled symbols represent zero larvae. Black lines represent constant density at 1 sigma- $t$ unit. Species abbreviations - AS: Anomia simplex; GD: Geukensia demissa; MM: Mercenaria mercenaria. Site abbreviations - LR: Little River; CR: Childs River; MN: Menauhant; WB: Waquoit Bay-Metoxit Point

tion of Mercenaria mercenaria at Little River. The only significant correlation with salinity was negative for A. simplex at Menauhant in $2007(\mathrm{r}=-0.615)$.

There were a few significant correlations with chl a in 2007, but they were low and possibly not biologically relevant. Waquoit Bay chl a was negatively cross-correlated with Geukensia demissa larvae $(\mathrm{r}=$ -0.44 ), and Childs River chl a was positively crosscorrelated with Anomia simplex (0.47). We used phytoplankton counts for a better estimate of larval food abundance. Comparing larval abundances to the presence of phytoplankton from the counts (Fig. 3), higher survival in the later months of 2009 may be attributed to the diatom bloom at many of the sites, which was absent in 2007. For all correlation coefficients see Figs. S3 \& S4 in the supplement.

\section{Synthesis}

Based on the information in this study, the proposed mechanism for higher concentrations and sizes in 2009 compared to 2007 is that initially cooler temperatures delayed mass spawning but wetter conditions encouraged phytoplankton growth. Once species spawned, temperatures increased and diatoms were abundant, encouraging rapid growth and better survival of larvae. Higher wind speeds led to 


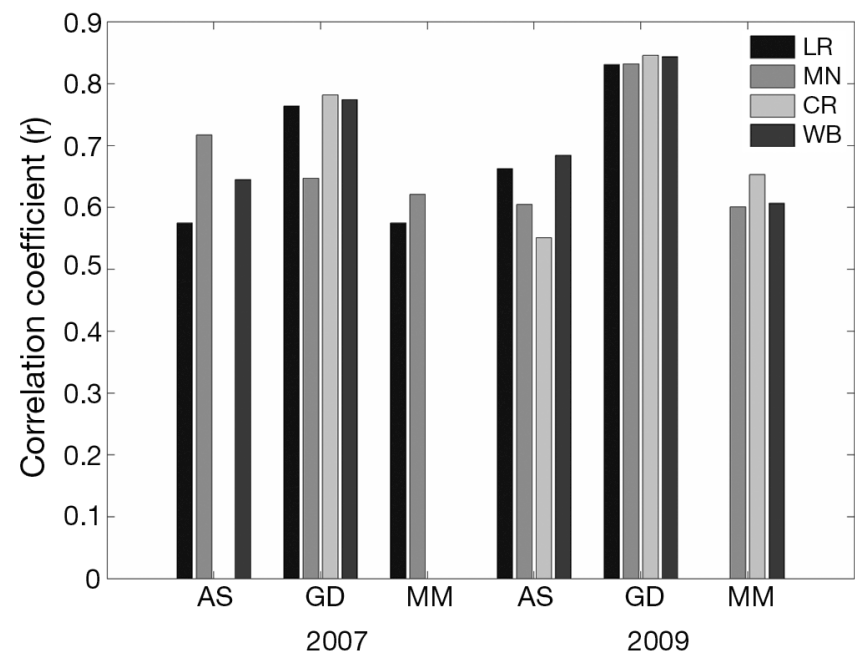

Fig. 10. Correlation coefficients for each larval concentration time series and water temperature during sample collection. Correlation coefficients are Pearson's $\mathrm{r}$ and are significant for alpha $=0.05$. Species abbreviations - AS: Anomia simplex; GD: Geukensia demissa; MM: Mercenaria mercenaria. Site abbreviations — LR: Little River; CR: Childs River; MN Menauhant; WB: Waquoit Bay-Metoxit Point

more circulation in the bay, causing larvae to be transported further upstream and retained.

\section{DISCUSSION}

The purpose of this study was to investigate environmental factors that could influence larval abundances on a weekly scale. We were able to document 2 very different years in terms of biological and physical characteristics, and we propose this had a pronounced effect on larval concentrations and survival. Larval growth depends mainly on nutritional factors, and larval survival depends on predation, advection, and initial density (Fegley 2001). We used density of veliger and pediveliger larvae to interpret larval survival which may also imply successful growth; however, growth rates were not calculated as we would have to successfully isolate cohorts and assume no larval loss. This study suggests annual patterns in water temperature and food availability can lead to yearly fluctuations in larval abundance. These differences can affect potential settling of adults, emphasizing the importance of recognizing larval stages to explain population dynamics in management applications. Because enhancement efforts can rely heavily on spat collection to measure recruitment, knowing optimal times and locations to place collectors is valuable to maximizing returns.

\section{Species-specific concentration and size}

We compared species-specific yearly differences in larval abundance and survival, which is rare for studies of bivalve larvae. The few field studies that have been performed on Mercenaria mercenaria reported large differences in abundance between years (Carriker 1961, Fegley 2001). Despite its commercial importance to the area, there is little documentation of $M$. mercenaria spawning for Cape Cod. Spawning temperatures for $M$. mercenaria near New Bedford, Massachusetts, have been reported at $21^{\circ} \mathrm{C}$ and can occur as low as 18 to $19^{\circ} \mathrm{C}$ in more northern areas (Eversole 2001). Spawning of M. mercenaria has been documented for areas south of Long Island from June to November (Loosanoff et al. 1951, Keck et al. 1975). Our study showed that $M$. mercenaria larvae were present in low concentrations as early as midMay in both 2007 and 2009 at water temperatures $>16^{\circ} \mathrm{C}$. A Rhode Island study performed in 1954 found larvae appearing by the end of May, with highest abundances of $M$. mercenaria larvae in mid- to late June; however, late July and August had the highest concentrations in our study (Fegley 2001). Carriker (1961) found larvae appearing in late May, with highest densities in July when sampling from 1948 to 1951 in Little Egg Harbor, New Jersey. The differences between our study and older studies of M. mercenaria could reflect differences in regional populations as well as possible adaptations to climate change.

Mercenaria mercenaria had a coherent population structure within Waquoit Bay in 2009, as both abundance and sizes were correlated between sites, indicating the population was well dispersed and uniform throughout the bay. There was less coherence in 2007. Results indicated that Little River and Waquoit Bay could be source or spawning locations, as larvae were more abundant and initially appeared there. A major biomass and high-density source of spawning quahogs was located in a 10 ha shellfish aquaculture farm in the Seapit River that flows tidally between Waquoit Bay and Childs River. The tidal direction during a major spawning period would determine the concentration of larvae from the spawn transported to the main bay. Tides flowing in the Childs River direction during a big spawn in 2007 might explain the high concentrations observed there and at Menauhant with other sites lagging behind, with larvae ultimately succumbing to low salinities or export. In 2009, a tide flowing in the opposite direction might explain the high concentrations and retention of $M$. mercenaria in the main bay. 
The highest abundance of $M$. mercenaria pediveligers was in August 2009 at all sites, with Childs River in particular having a high proportion of pediveliger larvae. This may be due to lower salinities in Childs River discouraging pediveliger larvae from settling and causing them to remain in the water column. $M$. mercenaria spawned again later in the season and may have settled at Little River and the main bay, despite not growing as fast as in mid-summer. In 2011, 2 yr old $M$. mercenaria made up a large portion of adults and most of the seed in the Waquoit Bay population (R. York unpubl. data). This can now be traced to the favorable conditions and high larval supply in mid-summer 2009.

For the jingle clam Anomia simplex, different conclusions can be made. Abundance and population structure were separated between sides of the bay, and no correlations between abundances and sites were observed in 2007 when overall concentrations were low. Little River was a likely source population, and early 2007 data indicated a possible source of $A$. simplex larvae from the inlet. However, A. simplex did not seem to stay in Little River, as more pediveligers were found in Menauhant and the main bay. There was some evidence for this species to be found in bay waters on ebb tides, supporting an estuarine source and export for A. simplex. More upstream transport from the inlet may have caused A. simplex abundance in Childs River to be correlated with Menauhant in 2009. As the adult lifespan for A. simplex is only 1 to 2 yr (Chanley \& Andrews 1971), yearto-year differences in larval abundance would depend on the previous year's recruitment and might explain the patchiness and inconsistencies observed between years. The multitude of peaks in the time series suggest $A$. simplex spawns continuously, and our data suggest these spawns may come from different locations. Larval periods of 3 to $4 \mathrm{wk}$ are typical for this species (Chanley \& Andrews 1971), so retention in the bay system may be difficult.

Despite both Mercenaria mercenaria and Anomia simplex achieving sizes that could lead to settlement in Waquoit Bay, Geukensia demissa larvae showed little evidence of survival to pediveligers or retention in 2009 despite maintaining stable concentrations in the bay with well-mixed populations. It is likely that marsh areas in the bay and channels like Little River were sources of larvae for G. demissa, though some larvae were found in the inlet site early in 2009. G. demissa spawned with 2 to 3 distinct cohorts, but the middle cohort that had the highest concentrations did not result in many pediveligers observed later. It remains uncertain why G. demissa had reduced sur- vival compared to the other species when all were present concurrently. Food availability was better in the early and later periods, and G. demissa may have been more vulnerable to export. Rigal et al. (2010) found that tidal efflux resulted in a lack of settlement-stage gastropod larvae in an embayment. For instance, larvae spawned in marsh channels on an outgoing tide could be instantly flushed out of the bay and not retained as well as $M$. mercenaria larvae spawned in the middle of the bay and caught in a gyre or transported to a channel with higher retention times.

\section{Spatial patterns in concentration}

Time series of abundances at different sites can allow for predictions of dispersal. Larval abundance at most sites was autocorrelated for a maximum of $2 \mathrm{wk}$, which is on the order of water residence times and the larval development period. Each species had different trends: Anomia simplex was the least dispersed, but Geukensia demissa and Mercenaria mercenaria were well dispersed at times, particularly during 2009. This suggests that there are both periods of limited dispersal and homogeneity throughout a spawning season for different species. Other studies have failed to show temporal correlations between sites with younger $M$. mercenaria larvae, but older larvae were found to be more dispersed, although these studies were performed over a greater spatial range (Fegley 2001). Childs River often showed distinct abundance patterns from the other sites, which could be a result of its upstream location, lower salinities, higher nutrients, and longer retention times (Tomasky-Holmes 2008).

There are several physical factors that may have contributed to the observed differences in larval abundance. All sites were separated by only 1 to $2 \mathrm{~km}$, thus the sometimes large differences in concentrations between sites emphasize the patchiness within the system. Flow dynamics through an inlet are different than flow through estuarine channels and open water. In Waquoit Bay, the inlets have the strongest flows and exchange water rapidly with the main bay. Flows through sub-embayments vary, exchanging waters over 1 to $3 \mathrm{~d}$ with the bay proper, but have much longer residence times within the whole bay system due to marsh storage areas (Howes et al. 2004). In addition, sporadic wind forcing from the north can disrupt stratification and lead to increased flushing of the bay (Geyer 1997), which may be responsible for occasional decreases in con- 
centration. Increased wind speeds in 2009 could have led to increased mixing and transport in the bay and could account for the larger presence of larvae, particularly Anomia simplex and large Mercenaria mercenaria larvae, upstream at Childs River.

\section{Relationships with environmental conditions}

We looked at larval abundance over $2 \mathrm{yr}$ when environmental conditions within the bay differed

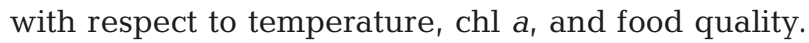
We chose these conditions based on environmental influences that may operate on our weekly sampling scale. Other factors, such as tidal flow and wind stress, need to be investigated at higher frequencies (i.e. Roegner et al. 2007). If we use total abundance as a proxy for spawning activity, spawning was less in 2007 despite higher temperatures. In 2009, bivalve larval concentrations for the Waquoit Bay site were as large as $90 \mathrm{l}^{-1}$, with individual species' concentrations ranging from 8.5 to $22 \mathrm{l}^{-1}$. This is extremely high, even for an estuary, and may indicate multiple mass spawnings. Typical reported peaks range from a few hundred to thousand bivalves per cubic meter (Wood \& Hargis 1971, Andrews 1983, Garland 2000), although reported densities from Carriker (1961) were up to $70 \mathrm{l}^{-1}$. This suggests Waquoit Bay is an abundant pool of bivalve larvae when conditions are right.

Temperature was revealed to be important in predicting larval abundance. Abundances of each species indicated that $20^{\circ} \mathrm{C}$ and above are optimal temperatures for larval abundance, most likely due to peak spawning. In 2009, spawning for Geukensia demissa occurred later than in 2007 because temperatures warmed up later in 2009. This delayed spawn could have led to the higher larval concentrations observed if adult gonads were allowed to ripen longer. Correlations with temperature were seen at all sites both years, but they were highest in 2009 . Mercenaria mercenaria was the only species found consistently present below $20^{\circ} \mathrm{C}$. Temperature has been shown to have significant correlations with larval abundance of other bivalve and reef fish in other studies (Chicharo \& Chicharo 2001, Wilson \& Meekan 2001), most likely due to the role it plays in increasing metabolic and growth rates, as well as the growth of algae, which can be good for survivorship if enough food is present.

Salinity and chl a showed weaker correlations with larval abundance. Salinity did not vary much tempo- rally, but showed variations between sites. Negative cross-correlations with Anomia simplex and salinity at Menauhant in 2007 suggest that there could have been a tidal effect, with more larvae present on outgoing tides, but this pattern is not necessarily causation and merits further investigation on a tidal scale (Thompson 2011). Site-specific differences in salinities highlight potential larval tolerances for each species, and low salinities can reduce survivorship of sensitive species. Geukensia demissa had the highest abundance during low salinity periods in Childs River, and A. simplex was the least tolerant of lowsalinity conditions. However, this relationship could also be explained by proximity to sources or different patterns in dispersal between species. Although we did see some significant correlations with chl $a$, these were weak and suggest that larvae are not necessarily associated with areas of high or low chl a. It is possible that the extremely high concentrations of larvae associated with these samples were effective at grazing the phytoplankton down to the lower levels observed, particularly for 2009. In 2007, blooms of large dinoflagellates at Childs River created a lot of turbidity and could be a deterrent to larvae. Overall, relationships to chl a were inconsistent, and it may be necessary to investigate this question with higher frequency sampling to see any patterns (Domingues et al. 2011). Other field studies of bivalve larvae have also failed to find associations with chl a (Tremblay \& Sinclair 1990, Raby et al. 1994).

\section{Food quality}

We compared the abundance of diatoms, a quality larval food source, and flagellates, usually a mediocre food source, for both years. There was very little available phytoplankton that would be suitable for larval ingestion and growth in May and June of 2007. Together with higher temperatures, this would have led to more starvation in these cohorts. Diatom blooms coinciding with higher temperatures in July and August 2009 could have led to their increased survival.

In 2007, lower numbers of pediveligers could suggest that low food quality may have limited larval survival and growth, although other food sources may have been present. Bivalve larvae typically consume food particles in the pico- to nano-plankton size range of 0.5 to $12 \mu \mathrm{m}$, occasionally ingesting large particles up to $30 \mu \mathrm{m}$ if abundant (Baldwin \& Newell 1995). However, it is well documented that bivalve larvae are capable of ingesting bacteria (Douillet 
1993, Gallager et al. 1994, Tomaru et al. 2000), although it mostly supplements growth on a phytoplankton-based diet (Baldwin \& Newell 1991). Larvae can grow in estuarine conditions with low natural phytoplankton abundances, although growth patterns are species specific (Crisp et al. 1985) and diets are likely supplemented with bacteria or detritus (Fritz et al. 1984). Larvae can continue shell growth without food by depleting tissue for energy (Crisp et al. 1985).

More predation could explain the observed low abundance of pediveliger larvae in 2007 if food was not limiting. Although predation may be relatively low for larvae overall, certain predators, if abundant, are capable of reducing a bivalve larval population by upwards of $80 \%$ (Johnson \& Shanks 2003). In 2007 the ctenophore Mnemiopsis leidyi was more abundant than in 2009 (C. M. Thompson pers. obs.) and could have reduced larval abundance through topdown control.

\section{CONCLUSIONS}

By performing a species-specific study using a new method to identify bivalve larvae, we were able to depict spatial and temporal trends and uncover environmental factors that may regulate larval supply for each species. We observed general patterns affecting larval abundance, such as seasonal temperature and site-specific salinity differences, which are likely to have the greatest effect on survivability. Speciesspecific patterns suggested that for a commercial species like Mercenaira mercenaria, higher recruitment based on larval supply alone would likely be achieved in a year where high temperatures are coupled with abundant quality food. For an ecologically important species like Geukensia demissa, our study suggests that larval survival was low and that larval supply may be subsidized from other marshes or limited to the few individuals retained in high-retention areas of the bay. We used cross-correlation analyses to determine whether such characteristics had a relationship with larval abundance; however, these results are correlative but not necessarily causation. There could be many other mechanisms leading to the observed patterns in larval abundance and survival that were not investigated in this study, such as tidal flow, wind-driven transport, or environmental conditions and spawning rates from nearby populations. Furthermore, we did not test correlations separately for size classes which can sometimes lead to different patterns (Fegley 2001). Because Waquoit
Bay has abundant shellfish resources for both recreational and commercial fisheries and such a high abundance of larvae, a study such as ours is necessary to understand the factors regulating these valuable resources and to managing future populations and biodiversity.

Acknowledgements. The authors thank the Waquoit Bay National Estuarine Research Reserve staff for their help and expertise with sampling, data, equipment, and logistics for this study. We especially thank C. Weidman, M. K. Fox, and E. Bonk. Field assistance was provided by M. Potter, A. York, C. Mingione, and M. Mingione. V. Starczak and R. Horwitz assisted with data interpretation and statistical analysis. We also thank C. Swain of Edwards Boat Yard, Falmouth, MA, M. Loftus of the Menauhant Yacht Club, Falmouth, MA, and P. Ellis, Mashpee Harbormaster, Mashpee, MA, for allowing access to sampling locations. This research was conducted in the National Estuarine Research Reserve System under an award to S. Gallager and C. Mingione Thompson from the Estuarine Reserves Division, Office of Ocean and Coastal Resource Management, National Ocean Service, National Oceanic and Atmospheric Administration.

\section{LITERATURE CITED}

Andrews JD (1983) Transport of bivalve larvae in James River, Virginia. J Shellfish Res 3:29-40

Baldwin BS, Newell RIE (1991) Omnivorous feeding by planktotrophic larvae of the eastern oyster Crassostrea virginica. Mar Ecol Prog Ser 78:285-301

Baldwin BS, Newell RIE (1995) Relative importance of different size food particles in the natural diet of oyster larvae (Crassostrea virginica). Mar Ecol Prog Ser 120: 135-145

Bayne BL (1965) Growth and the delay of metamorphosis of the larvae of Mytilus edulis (L.). Ophelia 2:1-47

$>$ Belgrano A, Legendre P, Dewarumex JM, Frontier S (1995) Spatial structure and ecological variation of meroplankton on the Belgian-Dutch coast of the North Sea. Mar Ecol Prog Ser 128:51-59

Bertness MD (1984) Ribbed mussels and Spartina alterniflora production in a New England salt marsh. Ecology 65:1794-1807

Boicourt WC (1988) Recruitment dependence on planktonic transport in coastal waters. In: Rothschild BJ (ed) Toward a theory on biological-physical interactions in the world ocean. Kluwer Academic Publishers, Amsterdam, p 183-202

> Botsford LW, Moloney CL, Hastings A, Largier JL, Powell TM, Higgins K, Quinn JF (1994) The influence of spatially and temporally varying oceanographic conditions on meroplanktonic metapopulations. Deep-Sea Res II 41: 107-145

> Botsford LW, Wing SR, Largier JL (1998) Population dynamics and management implications of larval dispersal. S Afr J Mar Sci 19:131-142

Brousseau DJ (1977) Spawning cycle, fecundity, and recruitment in a population of soft-shell clam, Mya arenaria, from Cape Ann, Massachusetts. Fish Bull 76:155-166

Carriker MR (1961) Interrelation of functional morphology, behavior, and autecology in early stages of the bivalve, 
Mercenaria mercenaria. J Elisha Mitchell Sci Soc 77 : 168-241

Carriker MR (1988) Bivalve larval research, in transition: a commentary. J Shellfish Res 7:1-6

Chanley P, Andrews JD (1971) Aids for identification of bivalve larvae of Virginia. Malacologia 11:45-119

Chicharo L, Chicharo MA (2001) Effects of environmental conditions on planktonic abundances, benthic recruitment and growth rates of the bivalve mollusc Ruditapes decussates in a Portuguese coastal lagoon. Fish Res 53: 235-250

Cowen RK, Sponaugle S (2009) Larval dispersal and marine population connectivity. Annu Rev Mar Sci 1:443-466

Crisp DJ, Yule AB, White KN (1985) Feeding by oyster larvae: the functional response, energy budget and a comparison with mussel larvae. J Mar Biol Assoc UK 65: 759-783

Davis HC, Calabrese A (1964) Combined effects of temperature and salinity on development of eggs and growth of larvae of $M$. mercenaria and $C$. virginica. Fish Bull 63: 643-655

Dekshenieks MM, Hofmann EE, Powell EN (1993) Environmental effects on the growth and development of eastern oyster, Crassostrea virginica (Gmelin, 1971), larvae: a modeling study. J Shellfish Res 12:241-254

> Domingues CP, Almeida MJ, Dubert J, Nolasco R and others (2011) Supply of crab larvae to an estuary in the eastern Atlantic upwelling system exhibits predictable and haphazard variation at different temporal scales. Mar Ecol Prog Ser 425:113-124

Douillet P (1993) Bacterivory in Pacific oyster Crassostrea gigas larvae. Mar Ecol Prog Ser 98:123-134

> Eckman JE (1987) The role of hydrodynamics in recruitment, growth, and survival of Argopecten irradians (L.) and Anomia simplex (D'Orbingy) within eelgrass meadows. J Exp Mar Biol Ecol 106:165-191

Emery WJ, Thomson RE (1997) Data analysis methods in physical oceanography. Pergamon Press, New York, NY

Eversole AG (2001) Reproduction in Mercenaria mercenaria. In: Kraeuter JN, Castagna M (eds) Biology of the hard clam. Elsevier, Amsterdam, p 221-260

Fegley SR (2001) Demography and dynamics of hard clam populations. In: Kraeuter JN, Castagna M (eds) Biology of the hard clam. Elsevier, Amsterdam, p 383-422

Fritz LW, Lutz RA, Foote MA, Van Dover CL, Ewart JW (1984) Selective feeding and grazing rates of oyster (Crassostrea virginica) larvae on natural phytoplankton assemblages. Estuaries 7:513-518

Gaines SD, Bertness MD (1992) Dispersal of juveniles and variable recruitment in sessile marine species. Nature 360:579-580

Gallager SM, Mann F, Sasaki G (1986) Lipid as an index of growth and viability in three species of bivalve larvae. Aquaculture 56:81-103

Gallager SM, Waterbury JB, Stoecker DK (1994) Efficient grazing and utilization of the marine cyanobacterium Synechococcus sp. by larvae of the bivalve Mercenaria mercenaria. Mar Biol 119:251-259

Garland ED (2000) Temporal variability and vertical structure in larval abundance: the potential roles of biological and physical processes. PhD dissertation, Massachusetts Institute of Technology/Woods Hole Oceanographic Institution, Woods Hole, MA

Garland ED, Zimmer CA (2002) Techniques for the identification of bivalve larvae. Mar Ecol Prog Ser 225:299-310
Geyer WR (1997) Influence of wind on dynamics and flushing of shallow estuaries. Estuar Coast Shelf Sci 44: 713-722

- Hare MP, Palumbi SR, Butman CA (2000) Single-step species identification of bivalve larvae using multiplex polymerase chain reaction. Mar Biol 137:953-961

Hodgson CA, Bourne N (1988) Effect of temperature on larval development of the spiny scallop, Chlamys hastata Sowerby, with a note on metamorphosis. J Shellfish Res 7:349-357

Howes B, Kelley WW, Ramsey JS, Samimy R, Schlezinger D, Ruthven T, Eichner E (2004) Linked watershed-embayment Model to determine critical nitrogen loading thresholds for the Quashnet River, Hamblin Pond, and Jehu Pond, in the Waquoit Bay system in the towns of Mashpee and Falmouth, Massachusetts. Massachusetts Estuaries Project, Massachusetts Department of Environmental Protection, Boston, MA

Johnson KB, Shanks AL (2003) Low rates of predation on planktonic marine invertebrate larvae. Mar Ecol Prog Ser 248:125-139

Jordan TE, Valiela I (1982) A nitrogen budget of the ribbed mussel, Geukensia demissa, and its significance in nitrogen flow in a New England salt marsh. Limnol Oceanogr $27: 75-90$

Jorgensen CB (1981) Mortality, growth, and grazing impact of a cohort of bivalve larvae, Mytilus edulis L. Ophelia 20:185-192

Kassner J, Malouf RE (1982) An evaluation of 'spawner transplants' as a management tool in Long Island's hard clam fishery. J Shellfish Res 2:165-172

> Keck RT, Maurer D, Lind H (1975) A comparative study of the hard clam gonad developmental cycle. Biol Bull 148: 243-258

> Levin LA (2006) Recent progress in understanding larval dispersal: new directions and digressions. Integr Comp Biol 46:282-297

> Litaker W, Duke CS, Kenney BE, Ramus J (1987) Short-term environmental variability and phytoplankton abundance in a shallow tidal estuary. Mar Biol 96:115-121

> Loosanoff VL, Davis HC (1963) Rearing of bivalve mollusks. Adv Mar Biol 1:1-136

Loosanoff VL, Miller WS, Smith PB (1951) Growth and setting of larvae of Venus mercenaria in relation to temperature. J Mar Res 10:59-81

Loosanoff VL, Davis HC, Chanley PE (1966) Dimensions and shapes of larvae of some marine bivalve mollusks. Malacologia 4:351-435

Mann R (1988) Field studies of bivalve larvae and their recruitment to the benthos: a commentary. J Shellfish Res 7:7-10

Orensanz JM, Parma AM, Iribarne OO (1991) Population dynamics and management of natural stocks. In: Shumway SE (ed) Scallops: biology, ecology, and aquaculture. Elsevier, NY, p 625-713

> Pechenik JA, Eyster LS, Widdows J, Bayne BL (1990) The influence of food concentration and temperature on growth and morphological differentiation of blue mussel Mytilus edulis L. larvae. J Exp Mar Biol Ecol 136:47-64

> Pineda J, Hare JA, Sponaugle S (2007) Larval transport and dispersal in the coastal ocean and consequences for population connectivity. Oceanography (Wash DC) 20:22-39

> Raby D, Lagadeuc Y, Doson JJ, Mingelbier M (1994) Relationship between feeding and vertical distribution of bivalve larvae in stratified and mixed waters. Mar Ecol 
Prog Ser 103:275-284

Rigal F, Viard F, Ayata S, Comtet T (2010) Does larval supply explain the low proliferation of the invasive gastropod Crepidula fornicata in a tidal estuary? Biol Invasions

Roegner GC, Armstrong DA, Shanks AL (2007) Wind and tidal influences on larval crab recruitment to an Oregon estuary. Mar Ecol Prog Ser 351:177-188

Roughgarden J, Gaines SD, Possingham H (1988) Recruitment dynamics in complex life cycles. Science 241: 1460-1466

Scheltema RS (1986) On dispersal and planktonic larvae of benthic invertebrates: an eclectic overview and summary of problems. Bull Mar Sci 39:290-322

Shirley SM, Shirley TC (1989) Interannual variability in density, timing, and survival of Alaskan red king crab Paralithodes camtschatica larvae. Mar Ecol Prog Ser 54: 51-59

Starr M, Himmelman JH, Therriault JC (1991) Coupling of nauplii release in barnacles with phytoplankton blooms: a parallel strategy to that of spawning in urchins and mussels. J Plankton Res 13:561-571

Thompson CM (2011) Species-specific patterns in bivalve larval supply to a coastal embayment. $\mathrm{PhD}$ dissertation, Massachusetts Institute of Technology/Woods Hole Oceanographic Institution, Woods Hole, MA

Thompson CM, Hare MP, Gallager SM (2012) Semiautomated image analysis for the identification of bivalve larvae from a Cape Cod estuary. Limnol Oceanogr Meth 10:538-554

Thorson G (1950) Reproductive and larval ecology of marine bottom invertebrates. Biol Rev Camb Philos Soc 25:1-45

Tiwari S, Gallager SM (2003a) Optimizing multiscale invariants for the identification of bivalve larvae. In: Proceed-

Editorial responsibility: Pei-Yuan Qian, Kowloon, Hong Kong SAR ings of the 2003 IEEE international conference on image processing, Barcelona, September 14-17

Tiwari S, Gallager SM (2003b) Machine learning and multiscale methods in the identification of bivalve larvae. In: Proceedings of the 9th IEEE international conference on computer vision, Nice, October 14-17

> Todd CD (1998) Larval supply and recruitment of benthic invertebrates: Do larvae always disperse as much as we believe? Hydrobiologia 375/376:1-21

> Tomaru Y, Kawabata S, Nakano S (2000) Consumption of picoplankton by the bivalve larvae of Japanese pearl oyster Pinctada fucata martensii. Mar Ecol Prog Ser 192: 195-202

Tomasky-Holmes G (2008) Nutrient supply, water residence time, temperature, and grazing as controls of size-fractionated phytoplankton biomass in shallow temperate estuarine ecosystems. PhD dissertation, Boston University, Boston, MA

Townsend DW, Cammen LM (1988) Potential importance of the timing of spring plankton blooms to benthic-pelagic coupling and recruitment of juvenile demersal fishes. Biol Oceanogr 5:215-229

> Tremblay MJ, Sinclair M (1990) Sea scallop larvae Placopecten magellanicus on Georges Bank: vertical distribution in relation to water column stratification and food. Mar Ecol Prog Ser 61:1-15

> Wilson DT, Meekan MG (2001) Environmental influences on patterns of larval replenishment in coral reef fishes. Mar Ecol Prog Ser 222:197-208

Wood L, Hargis WJ (1971) Transport of bivalve larvae in a tidal estuary. In: Crisp DJ (ed) Proceedings of the 4th European Marine Biology Symposium. Cambridge University Press, Cambridge, p 29-44

Submitted: March 1, 2012; Accepted: August 11, 2012 Proofs received from author(s): November 12, 2012 